\title{
Neuroprotective Effect of YM90K, an AMPA-Receptor Antagonist, against Delayed Neuronal Death Induced by Transient Global Cerebral Ischemia in Gerbils and Rats
}

\author{
Sachiko Kawasaki-Yatsugi, Shin-ichi Yatsugi, Kazuo Koshiya and Masao Shimizu-Sasamata \\ Neuroscience Research, Pharmacological Laboratory, Institute for Drug Discovery Research, Yamanouchi Pharmaceutical Co., Ltd., \\ 21 Miyukigaoka, Tsukuba, Ibaraki 305, Japan \\ Received December 16, 1996 Accepted March 31, 1997
}

\begin{abstract}
We investigated the neuroprotective effect of the $\alpha$-amino-3-hydroxy-5-methylisoxazole-4propionate (AMPA)-receptor antagonist YM90K in transient global ischemia models. In a gerbil model, transient ischemia was induced by bilateral common carotid artery (CCA) occlusion for $5 \mathrm{~min}$. On administration at $1 \mathrm{hr}$ after ischemia, the AMPA antagonists NBQX $(30 \mathrm{mg} / \mathrm{kg}, \mathrm{i}$.p. $\times 3)$ and $\mathrm{YM} 90 \mathrm{~K}(15$ $\mathrm{mg} / \mathrm{kg}$, i.p. $\times 3$ or $30 \mathrm{mg} / \mathrm{kg}$, i.p. $\times 3$ ) significantly reduced the delayed neuronal death in the hippocampal CA1 region from 4 days after bilateral CCA occlusion. Furthermore, YM90K $(30 \mathrm{mg} / \mathrm{kg}$, i.p. $\times 3)$ showed a neuroprotective effect even when given at $6 \mathrm{hr}$ after ischemia. In contrast, the $N$-methyl-D-aspartate receptor antagonists CGS19755, MNQX (30 mg $/ \mathrm{kg}$, i.p. $\times 3$, each) and $( \pm) \mathrm{MK}-801(10 \mathrm{mg} / \mathrm{kg}$, i.p.) were not effective on injection at $1 \mathrm{hr}$ after ischemia in this model. In a rat model, ischemia was induced by 4-vessel occlusion (4-VO) for $10 \mathrm{~min}$. YM90K was administered $60 \mathrm{~min}$ after reperfusion. Rectal and temporal muscle temperatures were maintained at the same level as in the control group for $6 \mathrm{hr}$. YM90K markedly prevented the development of delayed neuronal death from 7 days after 4 -VO at doses of 15 or $30 \mathrm{mg} / \mathrm{kg}, \mathrm{i} . \mathrm{p} . \times 3$, with neuroprotective efficacy similar to that in the gerbil model. These results suggest that the AMPA receptor plays a critical role in the development of the delayed neuronal death induced by transient global cerebral ischemia. They also suggest that the neuroprotective effect of YM90K is not related to its hypothermic effect.
\end{abstract}

Keywords: AMPA receptor, Global cerebral ischemia, Delayed neuronal death

Excessive increase in glutamate in the synaptic cleft constitutes an important factor in the post-ischemic development of neuronal damage in the brain (1). Glutamate antagonists are therefore considered a candidate therapy for the treatment of acute stroke. Numerous studies on the neuroprotective effect of $N$-methyl-Daspartate (NMDA)-type glutamate-receptor antagonists have been reported $(2-7)$. However, the use of NMDAreceptor antagonists is limited because of side effects they produce including psychotomimetic action (8), learning impairment (9) and vacuolization of cerebrocortical neurons $(10,11)$. Recently, the neuroprotective effects of $\alpha$-amino-3-hydroxy-5-methylisoxazole-4-propionate (AMPA)-type glutamate-receptor antagonists have been also reported in various experimental models of cerebral ischemia (12). Among these, AMPA antagonists have reported to be more effective than NMDA antagonists in the global cerebral ischemia model $(13,14)$.
We have discovered YM90K [6-(1H-imidazol-1-yl)-7nitro-2,3(1H,4H)-quinoxlinedione monohydrochloride], an analog of quinoxalinedione, that has near-equal potency to NBQX [2,3-dihydroxy-6-nitro-7-sulfamoylbenzo $(F)$ quinoxaline] in blocking the AMPA receptor (15). This compound was shown to be effective on postischemic administration in focal cerebral ischemia in rats $(16,17)$ and cats $(18)$ and to be more effective than NBQX as assessed by audiogenic seizure in DBA/2 mice (17). In the present study, we investigated the protective effect of YM90K against delayed neuronal death (DND) in transient global cerebral ischemia in gerbils (19) and rats (20). In the gerbil model, we compared the efficacy of YM90K with that of other glutamate antagonists. In addition, we compared YM90K with NBQX with respect to the dosedependency of their effects and therapeutic time window in this model. We also conducted a dose-response study to compare the efficacy of YM90K in a rat 4-vessel occlu- 
sion (4-VO) model, with that in the gerbil model, and investigated whether the hypothermic effect of YM90K contributed to its neuroprotective action.

\section{MATERIALS AND METHODS}

\section{Bilateral common carotid artery (CCA) occlusion in gerbils}

Male Mongolian gerbils weighing 70-90 g (Seiwa Experimental Animal Laboratory, Inc., Fukuoka) were used. The bilateral CCAs were isolated under inhalation anesthesia with $1.5-2.0 \%$ halothane. With anesthetic inhalation stopped, the CCAs were ligated for 5 min using Sugita's microaneurysm clips (Keisei Medical Industrial Co., Ltd., Tokyo) followed by removal of the clips and reperfusion. The rectal temperature and temporal muscle temperature were maintained during surgery and CCA occlusion at $37.5 \pm 1{ }^{\circ} \mathrm{C}$ and $36.5 \pm 0.5^{\circ} \mathrm{C}$, respectively. All procedures were done in accordance with the guidelines of the Animal Ethical Committee of Yamanouchi Pharmaceutical Co., Ltd.

Effects of various glutamate antagonists given at $1 \mathrm{hr}$ after ischemia: YM90K and NBQX were administered intraperitoneally at doses of 15,30 and $60 \mathrm{mg} / \mathrm{kg}, 3$ times at $1 \mathrm{hr}(60,70$ and $85 \mathrm{~min})$ after reperfusion. CGS19755 (cis-4-phosphonomethyl-2-piperidine carboxylic acid) and MNQX (5,7-dinitro-quinoxaline-2,5-dione) were administered intraperitoneally at a dose of $30 \mathrm{mg} / \mathrm{kg}, 3$ times under the same time schedule. Because of its sustained action, $( \pm) \mathrm{MK}-801$ was given in a single dose of 10 $\mathrm{mg} / \mathrm{kg}$ at $60 \mathrm{~min}$ after reperfusion. Six animals were used per dose per group. Rectal temperature was monitored after reperfusion but not controlled.

In a separate experiment, saline or YM90K was given under the same time schedule as described above $(n=7$ per group). After administration, rectal temperature was maintained at $37 \pm 1{ }^{\circ} \mathrm{C}$ for $6 \mathrm{hr}$ after reperfusion using a heat lamp or cold water spray to evaluate the influence of post dosing changes in body temperature on the neuroprotective effect of YM90K.

Four days after surgery, animals were anesthetized with sodium pentobarbital $(50 \mathrm{mg} / \mathrm{kg}$, i.p.) and decapitated. The brains were removed and frozen in isopentane cooled with dry ice. Frozen sections $20 \mu \mathrm{m}$ in thickness were cut at $-20^{\circ} \mathrm{C}$ and stained with hematoxylin and eosin at several levels of the dorsal hippocampus. Neuronal cell loss in the hippocampal $\mathrm{CA} 1$ region was examined by light microscopy and scored for severity on a 4-point scale as follows:

No observable damage $=$ score 0 ,

$0-33 \%$ neuron damage of CA1 field $=$ score 1 ,

$34-66 \%$ neuron damage of CA1 field $=$ score 2 ,

$67-100 \%$ neuron damage of CA1 field $=$ score 3 .
Therapeutic time window of YM9OK and NBQX: Therapeutic time windows of YM90K and NBQX were investigated. YM90K $(30 \mathrm{mg} / \mathrm{kg} \times 3$, i.p.) was given at $3 \mathrm{hr}$ (180, 190 and $205 \mathrm{~min}), 6 \mathrm{hr}(360,370$ and $385 \mathrm{~min})$ or 12 hr (720, 730 and $745 \mathrm{~min})$ after reperfusion. Other groups received NBQX (30 mg/kg, 3 times) at 3 or $6 \mathrm{hr}$ after reperfusion under the same time schedule $(n=6$ per group). Histological examination was done as described above.

YM90K and other glutamate antagonists used in this study were synthesized at our laboratory. In all the above experiments, compounds except for MNQX were dissolved in saline. Solutions of YM90K and NBQX were adjusted to $\mathrm{pH} 9-10$ by the addition of $1 \mathrm{~N} \mathrm{NaOH}$. MNQX was suspended in a $0.5 \% \mathrm{wt} . / \mathrm{vol}$. methylcellulose (MC) solution. Control groups were injected with 5 $\mathrm{ml} / \mathrm{kg}$ vehicle per administration.

\section{4-VO in rats}

Male Wistar rats (Japan Clea Co., Ltd., Tokyo) weighing 270 to $300 \mathrm{~g}$ were used. The day before ischemia, the rats were anesthetized with sodium pentobarbital $(50 \mathrm{mg} / \mathrm{kg}$, i.p. $)$, the vertebral arteries were electrocauterized (MICRO-1D; Mizuho Ika, Tokyo), and both CCAs were isolated and a ligature was placed loosely around each vessel. The rats were then allowed to recover from surgery. The next day, they were anesthetized with $1-2 \%$ halothane and the CCAs were exposed. The anesthesia was stopped and the CCAs were ligated using Sugita's

Table 1. Effects of various glutamate antagonists on DND in gerbils

\begin{tabular}{|c|c|c|c|c|c|c|}
\hline \multirow{3}{*}{ Treatment } & \multirow{3}{*}{$\begin{array}{c}\text { Dose } \\
(\mathrm{mg} / \mathrm{kg}, \text { i.p. })\end{array}$} & \multirow{2}{*}{\multicolumn{4}{|c|}{$\begin{array}{c}\text { No. of hemispheres } \\
\text { Grade of DND }\end{array}$}} & \multirow{3}{*}{ Mediar } \\
\hline & & & & & & \\
\hline & & 0 & 1 & 2 & 3 & \\
\hline Saline & & 0 & 0 & 0 & 12 & 3 \\
\hline \multirow[t]{3}{*}{ YM90K } & $15 \times 3$ & 0 & 4 & 2 & 6 & $2.5^{*}$ \\
\hline & $30 \times 3$ & 6 & 4 & 2 & 0 & $0.5^{* * *}$ \\
\hline & $60 \times 3$ & 7 & 3 & 0 & 0 & $0^{* * *}$ \\
\hline Saline & & 0 & 0 & 0 & 12 & 3 \\
\hline \multirow[t]{2}{*}{ NBQX } & $15 \times 3$ & 0 & 0 & 2 & 8 & 3 \\
\hline & $30 \times 3$ & 5 & 3 & 4 & 0 & $1^{* *}$ \\
\hline Saline & & 0 & 0 & 0 & 6 & 3 \\
\hline $0.5 \% \mathrm{MC}$ & & 0 & 0 & 0 & 6 & 3 \\
\hline CGS19755 & $30 \times 3$ & 0 & 0 & 0 & 12 & 3 \\
\hline MNQX & $30 \times 3$ & 0 & 0 & 2 & 10 & 3 \\
\hline MK-801 & $10 \times 1$ & 0 & 0 & 0 & 12 & 3 \\
\hline
\end{tabular}

The antagonists were administered at $\mathbf{l} \mathrm{hr}$ after reperfusion. Grading scale is described in Materials and Methods. Significant decrease in DND at ${ }^{*} \mathrm{P}<0.05,{ }^{* *} \mathrm{P}<0.01$ (the Kruskal-Wallis $H$-test followed by the Steel test) vs respective saline-treated group. 


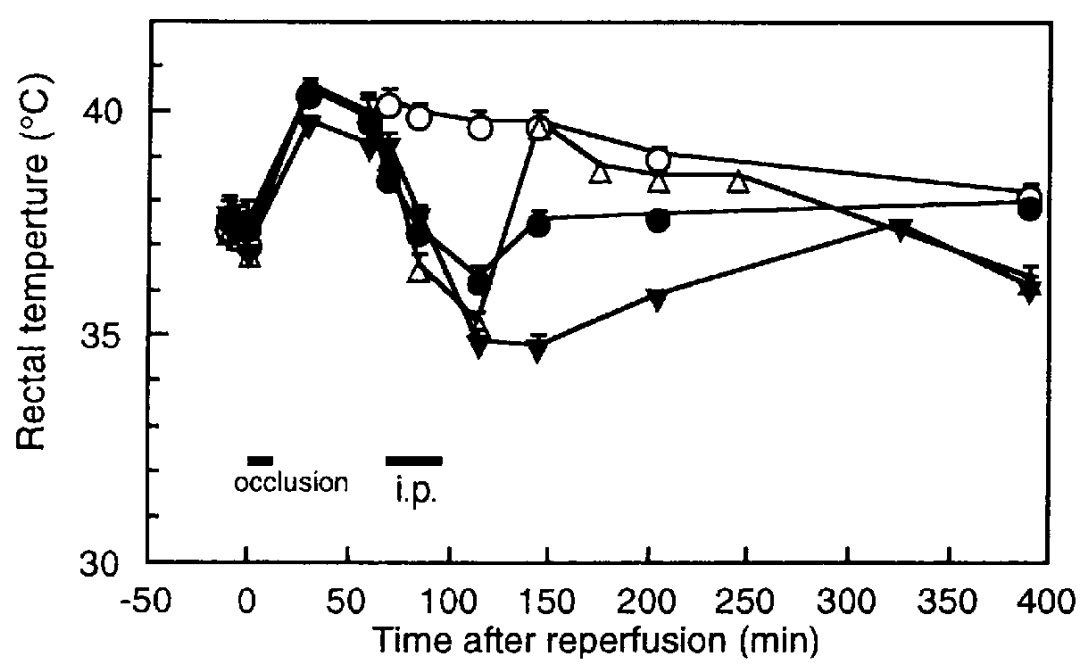

b

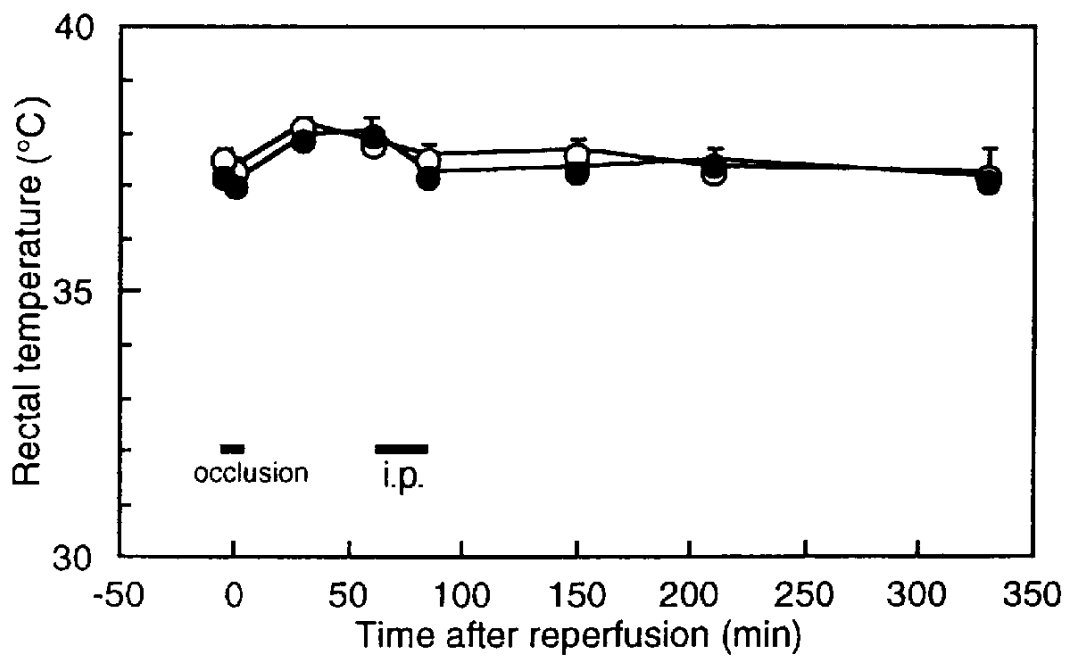

Fig. 1. Changes in rectal temperature in gerbils when it was uncontrolled after reperfusion (a) and maintained at around $37^{\circ} \mathrm{C}$ for $6 \mathrm{hr}$ after ischemia (b). Saline (O), YM90K (30 mg/kg, i.p. $\times 3)(\bigcirc)$, CGS19755 (30 mg/kg, i.p. $\times 3)(\boldsymbol{\nabla})$ and $( \pm)$ MK-801 $(10 \mathrm{mg} / \mathrm{kg}$, i.p.) $(\triangle)$ were administered $1 \mathrm{hr}$ after reperfusion. Data are expressed as means \pm S.E.M. $(\mathrm{n}=6)$.

Table 2. Effect of YM90K on DND when rectal temperature was regulated in gerbils

\begin{tabular}{lcrrrrrl}
\hline & & \multicolumn{4}{c}{ No. of hemispheres } & \\
\cline { 3 - 5 } Treatment & $\begin{array}{c}\text { Dose } \\
\text { (mg/kg, i.p. } \times 3)\end{array}$ & \multicolumn{4}{c}{ Grade of DND } & Median \\
\cline { 3 - 6 } & & 0 & 1 & 2 & 3 & \\
Saline & 30 & 10 & 2 & 2 & 0 & $0^{* *}$ \\
\hline
\end{tabular}

YM90K or saline was administered at $1 \mathrm{hr}$ after reperfusion. Rectal temperature was maintained around at $37^{\circ} \mathrm{C}$ for $6 \mathrm{hr}$. Grading scale is described in Materials and Methods. Significant decrease in DND at ${ }^{* *} \mathbf{P}<0.01$ (the Mann-Whitney $U$-test) vs saline-treated group. aneurysm clips for $10 \mathrm{~min}$. Animals that showed recovery of righting reflexes during ischemia were excluded. YM90K $(7.5,15$ or $30 \mathrm{mg} / \mathrm{kg}$, i.p. $\times 3)$ was administered at 60,75 and $90 \mathrm{~min}$ after reperfusion. The rectal and temporal muscle temperatures were maintained at the same level in the control group for $6 \mathrm{hr}$ after reperfusion using a heat lamp. Seven days after surgery, animals were anesthetized with sodium pentobarbital $(50 \mathrm{mg} / \mathrm{kg}$, i.p.) and perfusion-fixed with a transcardiac infusion of saline followed by $10 \%$ formalin neutral buffer solution. After perfusion, the rats were decapitated and the brains were removed. Coronal sections of paraffin-embedded 
brain, 7- $\mu \mathrm{m}$-thick, were cut, and sections were stained with hematoxylin-eosin at several levels of the dorsal hippocampus. Neuronal cell loss of the CAl field was examined as described for the gerbil model.

YM90K was suspended in a $0.5 \% \mathrm{wt} . / \mathrm{vol}$. MC solution. Control groups were injected with $2 \mathrm{ml} / \mathrm{kg}$ vehicle per administration.

\section{RESULTS}

\section{Bilateral CCA occlusion in gerbils}

The following deaths occurred within 4 days: 1 of 6 animals in each of the YM90K $(60 \mathrm{mg} / \mathrm{kg} \times 3)$ group $(1 \mathrm{hr}$ post treatment), YM90K $(30 \mathrm{mg} / \mathrm{kg} \times 3)$ group $(12 \mathrm{hr}$ post treatment), NBQX $(30 \mathrm{mg} / \mathrm{kg} \times 3)$ group $(6 \mathrm{hr}$ post treat-

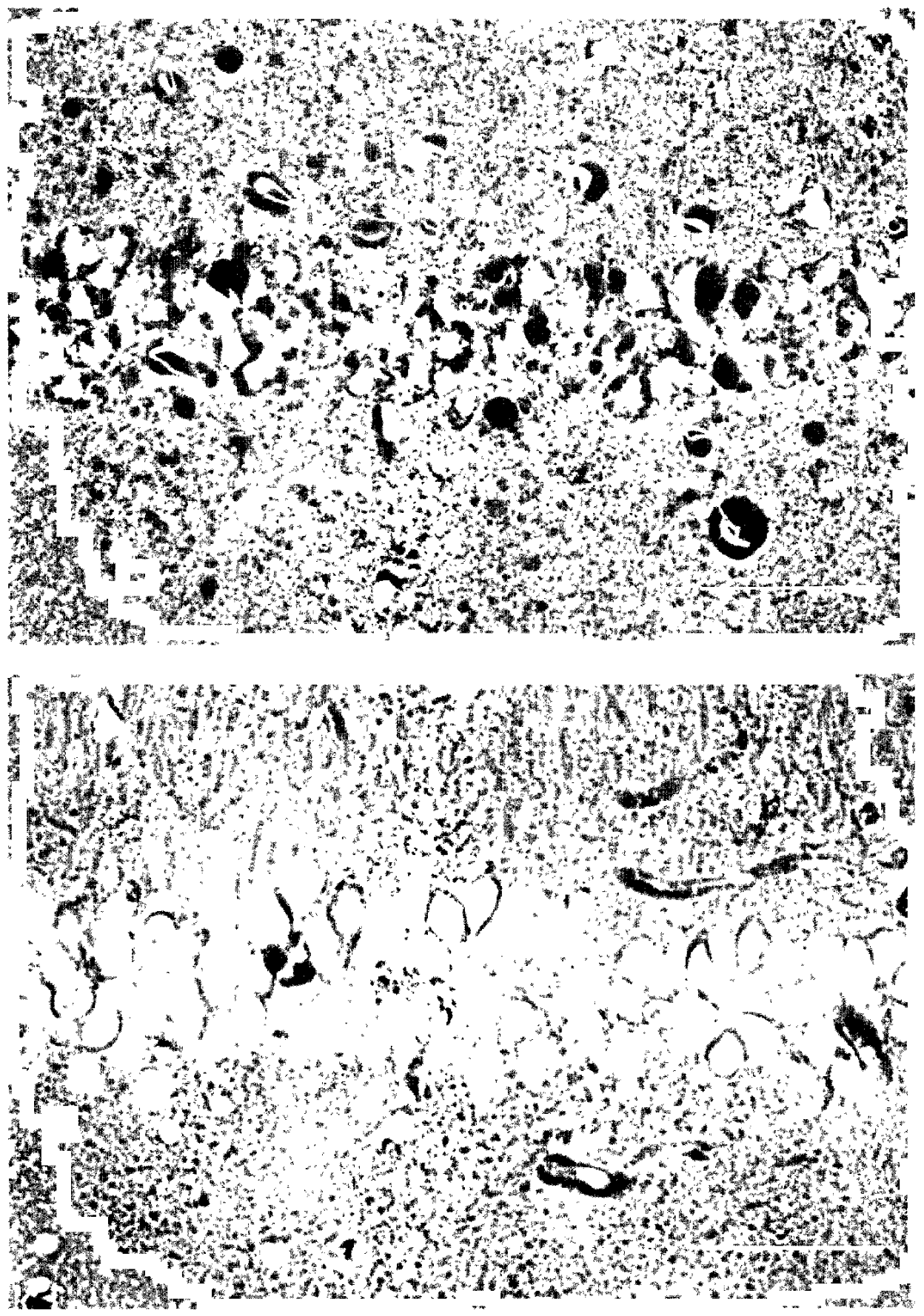

Fig. 2. Representative photographs of hippocampal CA1 pyramidal neurons four days after 5 min of ischemia. Hematoxyline-eosin staining. Magnification $=\times 500$, Scale bar $=50 \mu \mathrm{m}$. Upper: saline treatment. Almost all neurons in the CA1 region are damaged. Lower: YM90K treatment $(30 \mathrm{mg} / \mathrm{kg}$, i.p. $\times 3,1 \mathrm{hr}$ after reperfusion). CA1 pyramidal neurons are well-preserved. 
ment) and NBQX $(15 \mathrm{mg} / \mathrm{kg} \times 3)$ group (1 hr post treatment); 5 of 6 animals in the NBQX $(60 \mathrm{mg} / \mathrm{kg} \times 3)$ group ( $1 \mathrm{hr}$ post treatment); and 2 of 6 animals in the CGS19755-treated group.

Effect of various glutamate antagonists given at $1 \mathrm{hr}$ after ischemia: Complete DND was evident in the control animals (score: 3 ) when body temperature was not regulated. Both YM90K and NBQX markedly reduced the DND at a dose of $30 \mathrm{mg} / \mathrm{kg} \times 3$ (Table 1). The effect of YM90K in this administration schedule was dose-dependent. In contrast, NBQX showed no significant protective effect at $15 \mathrm{mg} / \mathrm{kg} \times 3$ (Table 1), while the high mortality at $60 \mathrm{mg} / \mathrm{kg} \times 3(5 / 6$ animals $)$ did not permit evaluation of effect. Since this compound has low water solubility, the high mortality at this dose may have been due to renal toxicity. NMDA-receptor antagonists CGS19755 and MNQX (both $30 \mathrm{mg} / \mathrm{kg} \times 3)$ and MK-801 $(10 \mathrm{mg} / \mathrm{kg}) \mathrm{had}$ little or no effect on DND (Table 1).

Figure 1a shows body temperature changes in pre- or post-ischemic period. After reperfusion, all animals exhibited an increase in rectal temperature (post-ischemic hyperthermia), which lasted for 3 to $4 \mathrm{hr}$ in the control animals. In the YM90K $(30 \mathrm{mg} / \mathrm{kg} \times 3)$-treated animals, the increased temperature fell progressively following administration and returned to the same level observed in the control animals at $6 \mathrm{hr}$ after reperfusion. This decrease in temperature was consistent with the degree of sedative effect. A hypothermic effect was also observed in CGS19755-treated animals, with the temperature remaining generally lower than that in the YM90K-treated animals. Animals given MK-801 showed fluctuations in rectal temperature.

Table 3. Therapeutic time window of YM90K and NBQX in gerbils

\begin{tabular}{|c|c|c|c|c|c|c|}
\hline \multirow{3}{*}{ Treatment } & & \multirow{2}{*}{\multicolumn{4}{|c|}{$\begin{array}{c}\text { No. of hemispheres } \\
\text { Grade of DND }\end{array}$}} & \multirow{3}{*}{ Median } \\
\hline & & & & & & \\
\hline & & 0 & 1 & 2 & 3 & \\
\hline \multirow[t]{3}{*}{$3 \mathrm{hr}$} & Saline & 0 & 0 & 0 & 6 & 3 \\
\hline & YM90K & 6 & 4 & 0 & 2 & $0.5^{*}$ \\
\hline & NBQX & 0 & 0 & 1 & 11 & 3 \\
\hline \multirow[t]{3}{*}{$6 \mathrm{hr}$} & Saline & 0 & 0 & 0 & 6 & 3 \\
\hline & YM90K & 3 & 4 & 1 & 4 & $1^{*}$ \\
\hline & NBQX & 1 & 0 & 0 & 9 & 3 \\
\hline \multirow[t]{2}{*}{$12 \mathrm{hr}$} & Saline & 0 & 0 & 0 & 6 & 3 \\
\hline & YM90K & 0 & 0 & 2 & 8 & 3 \\
\hline
\end{tabular}

YM90K, NBQX $(30 \mathrm{mg} / \mathrm{kg}$, i.p. $\times 3)$ or saline was administered at 3 , 6 or $12 \mathrm{hr}$ after reperfusion. Grading scale is described in Materials and Methods. Significant decrease in DND at ${ }^{*} \mathbf{P}<0.05,{ }^{* *} \mathbf{P}<\mathbf{0 . 0 1}$ (the Kruskal-Wallis $H$-test followed by the Steel test) vs respective saline-treated group.

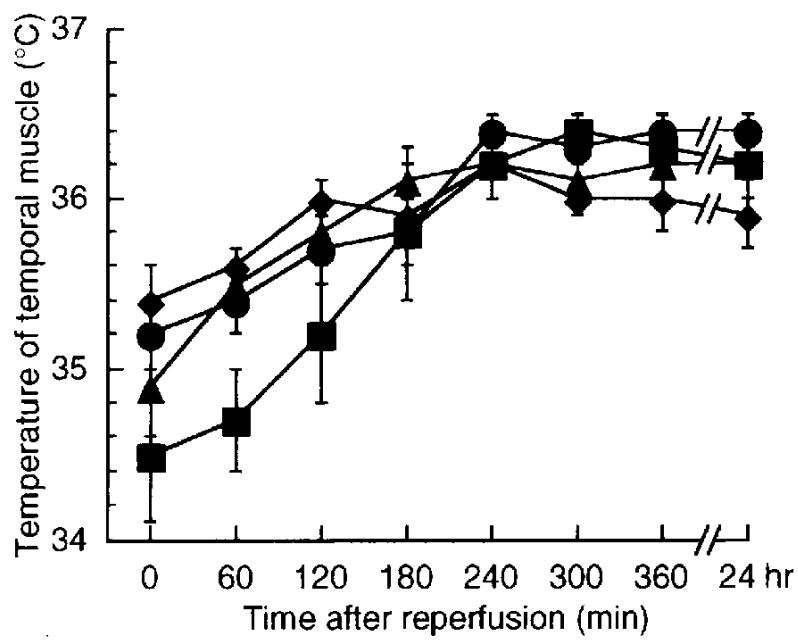

Fig. 3. Changes in temporal muscle temperature during and after ischemia in rats. Vehicle $(0.5 \% \mathrm{MC}$, i.p. $\times 3, \square ; n=10)$ or $\mathrm{YM} 90 \mathrm{~K}$ $(7.5(0), 15(\mathbf{A})$ or $30(-) \mathrm{mg} / \mathrm{kg}$, i.p. $\times 3 ; \mathrm{n}=8$, each) were administered at $1 \mathrm{hr}$ after reperfusion. Data are expressed as means \pm S.E.M.

When rectal temperature was regulated, no significant difference was observed in rectal temperature between the YM90K- and saline-treated animals from the time of occlusion to $6 \mathrm{hr}$ after reperfusion (Fig. $\mathrm{lb}$ ). Complete DND was evident in 6 of 7 animals of the control group (Table 2). In this experiment, a marked decrease in DND was also observed in the YM90K $(30 \mathrm{mg} / \mathrm{kg} \times 3)$ treated animals (Table 2, Fig. 2). The grade of protective effect of YM90K in this experiment was the same as that when body temperature was uncontrolled after reperfusion.

Therapeutic time window of YM9OK and $N B Q X$ : YM90K reduced the DND on administration at $3 \mathrm{hr}$ after reperfusion to the same marked extent as at $1 \mathrm{hr}$ after reperfusion (Table 3). A significant reduction was also seen with YM90K administered at $6 \mathrm{hr}$ after ischemia. However, no effect was seen on administration at $12 \mathrm{hr}$.

Table 4. Effect of YM90K on DND in rats

\begin{tabular}{lcrrrrrl}
\hline & & \multicolumn{5}{c}{ No. of hemispheres } & \\
\cline { 3 - 6 } Treatment & Dose & \multicolumn{5}{c}{ Grade of DND } & Median \\
& $(\mathrm{mg} / \mathrm{kg}$, i.p. $\times 3)$ & 0 & 1 & 2 & 3 & \\
\hline $0.5 \% \mathrm{MC}$ & & 4 & 0 & 0 & 16 & 3 \\
YM90K & 7.5 & 2 & 0 & 2 & 12 & 3 \\
& 15 & 12 & 0 & 1 & 3 & $0^{* *}$ \\
& 30 & 12 & 3 & 1 & 0 & $0^{* *}$
\end{tabular}

YM90K was administered at $1 \mathrm{hr}$ after reperfusion. Grading scale is described in Materials and Methods. Significant decrease in DND at ${ }^{* *} \mathbf{P}<0.01$ (the Kruskal-Wallis $H$-test followed by the Steel test) vs $0.5 \% \mathrm{MC}$-treated group. 
NBQX was ineffective after administration at 3 and $6 \mathrm{hr}$ after ischemia (Table 3).

\section{4-VO in rats}

There were no significant differences in temporal muscle temperature between the control and treatment groups (Fig. 3). Post-ischemic hyperthermia was not induced in this model. YM90K reduced the DND at 7 days after ischemia in a dose-dependent manner, with these reductions being marked at doses of 15 or $30 \mathrm{mg} / \mathrm{kg}$, i.p. $\times 3$ (Table 4).

\section{DISCUSSION}

In the present study, the AMPA-receptor antagonists YM90K and NBQX markedly reduced the DND on administration at $1 \mathrm{hr}$ after reperfusion in a gerbil transient ischemia model. YM90K reduced the DND even when administered $6 \mathrm{hr}$ after reperfusion in this model. These results suggest that the AMPA receptor plays an important role in the development of DND induced by global cerebral ischemia. In contrast, NMDA-receptor antagonists had little or no effect on the DND when administered $1 \mathrm{hr}$ after reperfusion. The reason for this lack of effect of NMDA-receptor antagonists in this administration schedule is considered to be in part due to the fact that the NMDA receptor is inactivated at low $\mathrm{pH}$ (21). The NMDA receptor could already be inactivated in the acidic condition following ischemia, and thus delayed blockade of this receptor by antagonists would exert limited efficacy.

Despite the fact that extracellular glutamate is rapidly restored to normal levels following reperfusion, YM90K and NBQX were effective even when administered late after reperfusion. These results suggest that ischemia leads to a long lasting functional change in the AMPA receptor and that this functional change contributes to the development of DND. Although the mechanism of this functional change is yet to be clarified, the following possibilities seem likely. First, an upregulation of the AMPA receptor, as observed during the maintenance phase of LTP (long-term potentiation), may take place (22). This upregulation could lead to increased depolarization of the neurons and influx of $\mathrm{Ca}^{2+}$ via VSCCs (voltage-sensitive calcium channels) and NMDA-receptor-gated channels. In addition, the increased intracellular concentration of $\mathrm{Na}^{+}$through the AMPA receptor and increased cell firing may also lead to reversal of the $\mathrm{Na}^{+}-\mathrm{Ca}^{2+}$ exchanger. Andinéet al. reported that following perforant path stimulation at $6 \mathrm{hr}$ after 4-VO for $20 \mathrm{~min}$, a larger decrease in extracellular $\mathrm{Ca}^{2-}$ levels, which was paralleled by an increase in intracellular $\mathrm{Ca}^{2+}$ concentration $\left(\left[\mathrm{Ca}^{2+}\right]_{i}\right)$, was observed in ischemic animals than in the controls (23). They demonstrated that there was a progressive increase in these $\mathrm{Ca}^{2+}$ shifts from 2 to $6 \mathrm{hr}$ and a significant correlation between stimulated $\mathrm{Ca}^{2+}$ uptake and CA1 hippocampal damage at 7 days postischemia. NBQX was able to eliminate these $\mathrm{Ca}^{2-}$ shifts completely (24). These results suggest that the AMPA receptor plays an important role in the elevation of $\left[\mathrm{Ca}^{2+}\right]_{i}$ in the postischemic period. These investigations may explain our results, namely, delayed treatment with AMPA antagonists could reduce DND in global ischemia models.

Second, although AMPA-receptor activation has been attributed to the depolarization of the membrane increasing $\mathrm{Na}^{+}$and $\mathrm{K}^{+}$ion fluxes in normal physiolosical condition, alternation in permeability of the AMPA receptor to $\mathrm{Ca}^{2+}$ may occur following ischemia. Pellegrini-Giampietro et al. (25) reported that expression of mRNA for the GluR2 subunit, which suppresses the $\mathrm{Ca}^{2+}$ permeability of the AMPA receptor (26), decreases in the CAl region after $10 \mathrm{~min}$ of ischemia in the rat 4-VO model. Thus, this change in $\mathrm{Ca}^{2+}$ permeability of the AMPA receptor may contribute to the cascade of events leading to cell death.

In the present study, YM90K was found to be more potent than NBQX, the effect of the former being evident at a lower dose. Furthermore, YM90K showed a wider therapeutic time window $(6 \mathrm{hr})$ than NBQX. The reason for these differences is unclear since the two compounds have similar affinity for the AMPA receptor, but possible differences in pharmacokinetic properties may underlie this discrepancy. In fact, YM90K has been shown to be almost equipotent to NBQX in audiogenic seizure tests when administered intracerebroventricularly, but about 3 times more potent than NBQX by the intraperitoneal route (17). This may suggest differences in pharmacokinetic profile between these compounds but not in intrinsic activity. Direct comparison of their pharmacokinetic properties, including blood-brain-barrier permeability, will clarify this point. NBQX was reported to be effective when administered at $24 \mathrm{hr}$ after ischemia in the gerbil global ischemia model (27) and also at $12 \mathrm{hr}$ after ischemia in the rat 4-VO model (28). In present study, however, it failed to produce any significant effect when administered at $3 \mathrm{hr}$ or later after reperfusion. The reason for this discrepancy is also unclear, but it may be due to a difference in animal colony and/or experimental technique.

Since changes in body temperature during and after ischemia influence the degree of neuronal damage (29-32), it is important to examine the effect of the drugs on body temperature (33). In our study, postischemic hyperthermia was suppressed in YM90K-treated gerbils until $6 \mathrm{hr}$ after reperfusion when body temperature was not regulated. Thus, in separate experiments, we regu- 
lated the body temperature after reperfusion in gerbils to determine whether this hypothermia contributed to its neuroprotective effect. The similar protective effect was observed when rectal temperature was regulated for $6 \mathrm{hr}$ after reperfusion. Busto et al. (30) reported the brain temperature changed in parallel to the rectal temperature after reperfusion but not during 20-min ischemia in the rat 4-VO model. They demonstrated that there was a precise relationship between temporal muscle temperature and brain temperature during and following ischemia. In the present rat 4-VO model study, temporal muscle temperature was monitored and maintained at the same level in control animals. YM90K also prevented the DND in rats to the same extent as in the gerbil model. These findings suggest that the neuroprotective effect of YM90K is not related to its hypothermic effect. In addition, no neuroprotective effect was observed in CGS19755-treated animals despite the production of a more profound hypothermia than that observed in YM90K-treated animals. This also suggests that the hypothermia alone does not provide protection against neuronal damage in our ischemia model in gerbils.

In conclusion, the present data indicates that the AMPA receptor plays an important role in the development of neuronal damage caused by global cerebral ischemia. They also suggest the importance of AMPAreceptor blockade in the treatment of disorders involving ischemic brain damage such as stroke and cardiac arrest.

\section{REFERENCES}

1 Benveniste H, Drejer J, Schousboe A and Diemer NH: Elevation of the extracellular concentrations of glutamate and aspartate in rat hippocampus during transient cerebral ischemia monitored by intracerebral microdialysis. J Neurochem 43, $1369-1374$ (1984)

2 Simon R, Swan J, Griffith T and Meldrum B: Blockade of $N$ methyl-D-aspartate receptors may protect against ischemic damage in the brain. Science 226, 850-852 (1984)

3 Gill R, Foster A and Woodruff GN: Systemic administration of MK-801 protects against ischemia-induced hippocampal neurodegeneration in the gerbil. J Neurosci 7, 3345-3349 (1987)

4 Park CK, Nehls DG, Graham DI, Teasdale GM and McCulloch J: The glutamate antagonist MK801 reduces focal ischaemic brain damage in the rat. Ann Neurol 24, 543-551 (1988)

5 Boast CA, Gerhardt SC, Pastor G, Lehmann J, Etienne PE and Liebman JM: The $N$-methyl-D-aspartate antagonists CGS19755 and $\mathrm{CPP}$ reduce ischemic brain damage in gerbils. Brain Res 442, 345-348 (1988)

6 Minematsu K, Fisher M, Li L and Sotak $\mathrm{CH}$ : Diffusion and perfusion magnetic resonance imaging studies to evaluate a noncompetitive $N$-methyl-D-aspartate antagonist and reperfusion in experimental stroke in rats. Stroke 24, 2074-2081 (1993)

7 Sauer D, Weber E, Luond G, Silva FD and Allegrini PR: The competitive NMDA antagonist CGP 40116 permanently reduces brain damage after middle cerebral artery occlusion in rats. J Cereb Blood Flow Metab 15, 602-610 (1995)

8 Kock W, Woods $\mathbf{J H}$ and Winger GD: MK-801, a proposed noncompetitive antagonist of excitatory amino acid neurotransmission, produces phencyclidine-like behavioral effects in pigeons, rats and rhesus monkeys, J Pharmacol Exp Ther 245, 969-974 (1988)

9 Morris RGM, Anderson E, Lynch GS and Baudry M: Selective impairment of learning and blockade of long-term potentiation by an $N$-methyl-D-aspartate receptor antagonist, AP5. Nature 319, 774-776 (1986)

10 Olney JW, Labruyere J and Price M: Pathlogical changes induced in cerebrocortical neurones by phencyclidine and related drugs. Science 244, 1360-1362 (1989)

11 Olney JW, Labruyere J, Wang G, Wozniak DF, Price MT and Sesma MA: NMDA antagonist neurotoxicity: mechanism and prevention. Science 254, 1515-1518 (1991)

12 Gill R: The pharmacology of $\alpha$-amino-3-hydroxy-5-methyl-4isoxazole propionate (AMPA)/Kainate antagonists and the role in cerebral ischaemia. Cerebrovasc Brain Metab Rev 6, 225-256 (1994)

13 Nellgård B and Wieloch T: Postischemic blockade of AMPA but not NMDA receptors mitigates neuronal damage in the rat brain following transient severe cerebral ischemia. J Cereb Blood Flow Metab 12, 2-11 (1992)

14 Buchan AM, Li H and Pulsinelli WA: The $N$-methyl-D-aspartate antagonist, MK801, fails to protect against neuronal damage caused by transient forebrain ischaemia in adult rats. J Neurosci 11, 1049 - 1056 (1991)

15 Ohmori J, Sakamoto S, Kubota H, Shimizu-Sasamata M, Okada M, Kawasaki S, Hidaka K, Togami J, Furuya T and Murase K: 6-(1H-Imidazol-1-yl)-7-nitro-2,3(1H,4H)-quinoxalinedione hydrochloride (YM90K) and related compounds: Structure-activity relationships for the AMPA-type non-NMDA receptor. J Med Chem 37, 467-475 (1994)

16 Shimizu-Sasamata M, Kawasaki S, Yatsugi S, Ohmori J, Sakamoto S, Koshiya K, Usuda S and Murase K: The neuroprotective action of YM900 (YM90K), a novel and potent AMPA antagonist, in a rat focal ischemia model. J Cereb Blood Flow Metab 13, Supp 1, S664 (1993)

17 Shimizu-Sasamata M, Kawasaki-Yatsugi S, Okada M, Sakamoto S, Yatsugi S, Togami J, Hatanaka K, Ohmori J, Koshiya K, Usuda S and Murase K: YM90K: Pharmacological characterization as a selective and potent $\alpha$-amino-3,5-methylisoxazole-4propionate (AMPA)/Kainate receptor antagonist. J Pharmacol Exp Ther 276, 84-92 (1996)

18 Yatsugi S, Takahashi M, Kawasaki-Yatsugi S, Koshiya K, Sakamoto S, Uematsu D and Shimizu-Sasamata M: Neuroprotective effect of YM90K, a novel AMPA/Kainate receptor antagonist, in focal ischemia in cats. J Cereb Blood Flow Metab 16, $959-966$ (1996)

19 Kirino T: Delayed neuronal death in gerbil hippocampus following ischemia. Brain Res 239, 57-69 (1982)

20 Pulsinelli WA and Brierley JB: A new model of bilateral hemispheric ischemia in the unanesthetized rat. Stroke 10, 267-272 (1979)

21 Giffard RG, Monyer H, Christine $\mathrm{CW}$ and Choi DW: Acidosis reduces NMDA receptor activaton, glutamate neurotoxicity, and oxygen-glucose deprivaton neuronal injury in cortical cultures. Brain Res 506, 339-342 (1990)

22 Davis SN, Lester RA, Reymann $\mathrm{KG}$ and Collingridge GL: 
Temporally distinct pre- and post-synaptic mechanisms maintain long-term potentiation. Nature 338, 400-503 (1989)

23 Andiné P, Jacobson I and Hagberg H: Calcium uptake evoked by electrical stimulation is enhanced postischemically and precedes delayed neuonal death in CA1 of rat hippocampus: involvement of $N$-methyl-D-aspartate receptors. J Cereb Blood Flow Metab 8, 799-807 (1989)

24 Andiné P, Jacobson I and Hagberg H: Enhanced calcium uptake by $\mathrm{CA} 1$ pyramidal cell dendrites in the postischemic phase despite subnormal evoked field potentials: Excitatory amino acid receptor dependency and relationship to neuronal damage. J Cereb Blood Flow Metab 12, 773-783 (1992)

25 Pellegrini-Giampietro DE, Zukin RS, Bennett MVL, Cho S and Pulsinelli WA: Swich in glutamate receptor subunit gene expression in CA1 subfield of hippocampus following global ischemia in rats. Proc Natl Acad Sci USA 89, 10499-10503 (1992)

26 Hollmann $\mathrm{M}$, Hartley $\mathrm{M}$ and Heinemann $\mathrm{S}: \mathrm{Ca}^{2+}$ permeability of KA-AMPA-gated glutamate receptor channels depends on subunit composition. Science 252, 851-853 (1991)

27 Sheardown MJ, Suzak PD and Nordholm L: AMPA but not NMDA, receptor antagonism is neuroprotective in gerbil ischemia, even when delayed $24 \mathrm{~h}$. Eur J Pharmacol 236, 347-353
(1993)

$28 \mathrm{Li} \mathbf{H}$ and Buchan AM: Treatment with an AMPA antagonist 12 hours following severe normothermic forebrain ischemia prevents CA1 neuronal injury. J Cereb Blood Flow Metab 13, 933-939 (1993)

29 Busto R, Dietrich WD, Globus MYT and Ginsberg MD: Postischemic moderate hypothermia inhibits CAl hippocampal ischemic neuronal injury. Neurosci Lett 101, 299-304 (1989)

30 Busto R, Dietrich WD, Globus MYT, Valdes I, Scheinberg P and Ginsberg MD: Small differences in intraischemic brain temperature critically determine the extent of ischemic neuronal injury. J Cereb Blood Flow Metab 7, 729-738 (1987)

31 Welsh FA, Smith RE and Harris VA: Mild hypothermia prevents ischemic injury in gerbil hippocampus. J Cereb Blood Flow Metab 10, 557-563 (1990)

32 Kuroiwa T, Bonnekoh P and Hossmann KA: Prevention of postischemic-hyperthermia prevents ischemic injury of CA1 neurons in gerbil. J Cereb Blood Flow Metab 10, 550-556 (1990)

33 Nurse S and Corbett D: Neuroprotection after several days of mild, drug induced hypothermia. J Cereb Blood Flow Metab 16, 474-480 (1996) 